ロ絵 2 : 島原半島ジオパーク一活火山と共生する人々がつくりだす世界ジオパーク一

\title{
Pictorial 2: Unzen Volcanic Area Geopark: Global Geopark Created by Human Beings Who Coexist with an Active Volcano
}

島原半島ジオパークは「活火山と人間との共生」をテーマとした世界ジオパークである．島原半島ジオパークの見どころは，雲仙火 山の火山活動や正断層がつくる独特の景観と地層にあるが，これらに加えて，火山災害からの復興の過程，1637 年に勃発した「島原・ 天草一揆」の歴史的遺構，温泉や湧水，肥沃な土潩，そしてそれらの恵みを活用することによって育まれた独自の文化もまた，島原半 島ジオパークの大きな構成要素である（末尾の数字は写真撮影日）.

The Unzen Volcanic Area Geopark is one of the Global Geoparks in Japan, and it has the theme of the coexistence between an active volcano and human beings. The highlights of the Geopark are outstanding landscapes and strata formed by active normal faults and Unzen Volcano. Furthermore, the processes of the local community's restorations from volcanic disasters, the Shimabara Rebellion in 1637, hot springs and spring water, fertile soil, and unique culture cultivated using the benefits of Unzen Volcano are also important contents of the Geopark (in parentheses is the date on which each photograph was taken).

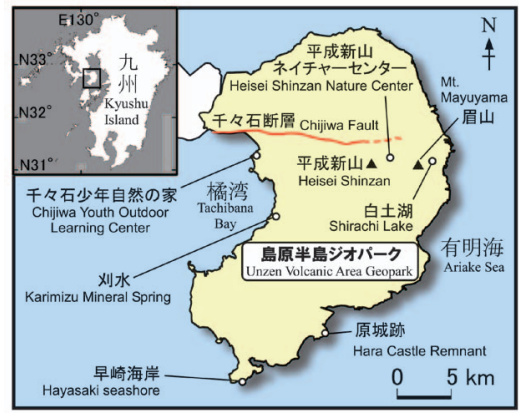

図 1 口絵 1 に用いた写真の撮影場所。千々不 断層の位置は渡辺·星住（1995）による。

Fig. 1 Local map of places where photos used here were taken. Position of Chijiwa fault is drawn referring to Watanabe and Hoshizumi (1995)

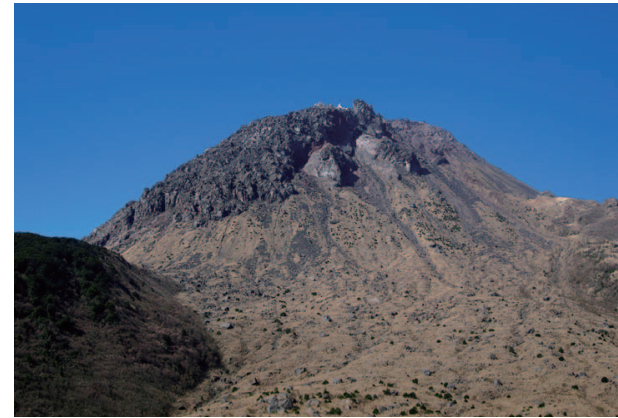

図 2 平成新山ネイチャーセンターからみた平成新山. 1991 年 5 月より開始されたデイサイトマグマの 噴出により，およそ 5 年かけて成長した溶岩ドー 厶 $(2010.3 .21)$

Fig. 2 Heisei Shinzan viewed from Heisei Shinzan Nature Center. Heisei Shinzan is a lava dome that grew for 5 years from May 1991 due to the extrusion of dacite magma (Mar. 21, 2010).

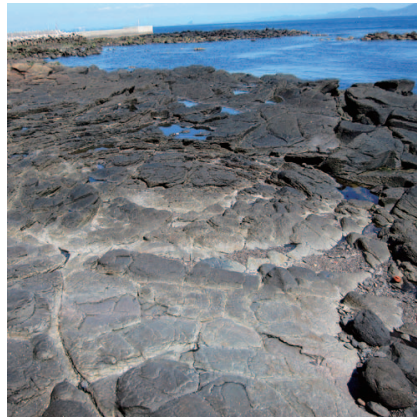

図 3 早崎海岸に露出する島原半島 最古の立武岩質溶岩流（早崎立 武岩）（2010.4.25）

Fig. 3 Basaltic lava flows exposed at Hayasaki seashore (Hayasaki Basalt), which is the oldest volcanic rock in Shimabara Peninsula (Apr. 25, 2010)

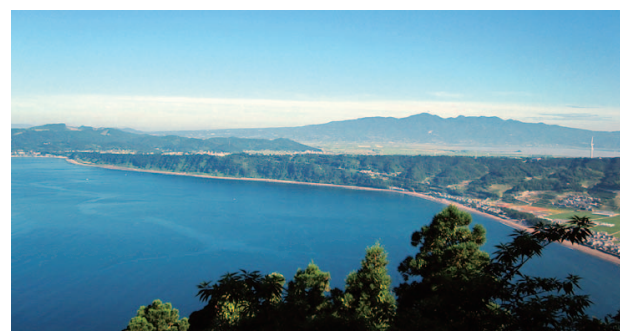

図 4 千々石少年自然の家からみた卓占方断層の断層崖. この断層の南 側 (写真手前側) の地面は, 1 〜 $\mathrm{mm} /$ 年の割合で沈降を続けて いる (2011.7.18)

Fig. 4 Fault scarp of Chijiwa fault viewed from Chijiwa Youth Outdoor Learning Center. The ground to the south of the fault has been sinking at a rate of 1-2 mm/year (July 18, 2011).

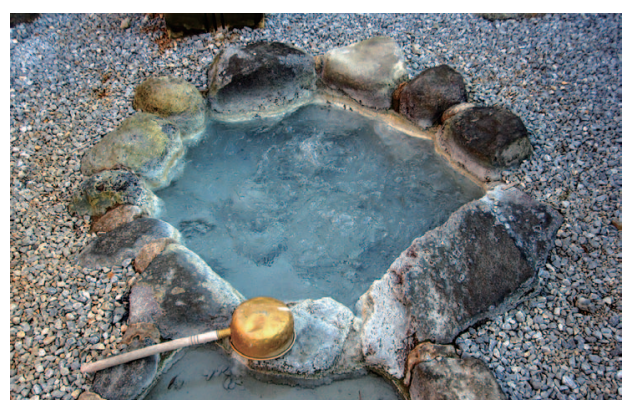

図 6 刈水一小浜温泉地域唯一の炭酸水素塩泉。この鉱泉の湧出温度は $30^{\circ} \mathrm{C}$ に満たず, 地面から硫化水素を含む二酸化炭素がほこぼこと 湧き出す (2010.10.27)

Fig, 6 Karimizu Mineral Spring, which is the only Sodium-Carbonated Hydrogen Mineral Spring in the Obama area. Source temperature of the spring is lower than 30 degrees in Celsius, and carbon dioxide gas including in hydrogen sulfide is emitted from the ground (Oct. 27, 2010).

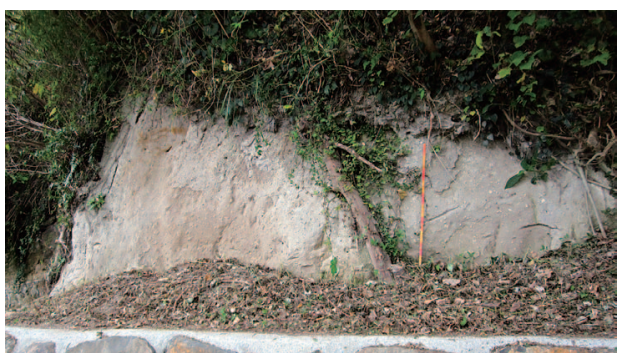

図 5 原城跡の海岸に露出する阿蘇 4 火砕流堆積物. 島原半島まで達し た阿蘇 4 火砕流（約 9 万年前）は，そこに城をつくるのに適した 高台を形成した（2010.11.16）

Fig. 5 Aso-4 pyroclastic flow deposit exposed at the seashore of Harajo Remnant. Aso-4 pyroclastic flow (about 90,000 years ago), which reached Shimabara Peninsula, formed a plateau that was suitable for building of a castle (Nov. 16, 2010).

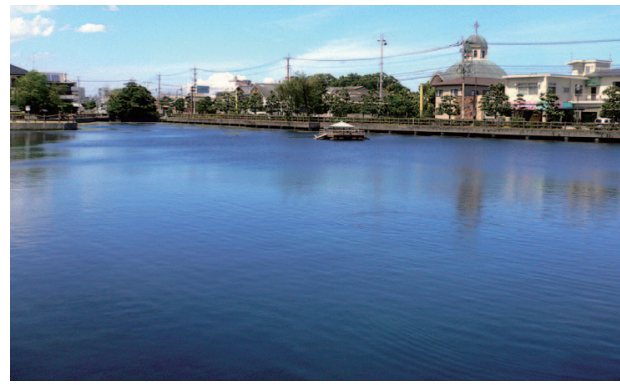

図 7 白土湖. 1792 年の雲仙普賢岳噴火の末期に生じた眉山溶岩ドー 厶の山体崩壊と地殼変動により, 周囲の井戸から大量の水が湧き 出してできた湖である（2009.7.14）。

Fig. 7 Shirachi Lake, which is a pond created by a large volume of concentrated ground water that gushed out around wells after Mt. Mayuyama collapsed in 1792 (July 14, 2009). 